The Agriculturists 16(2): 88-92 (2018) ISSN 2304-7321 (Online), ISSN 1729-5211 (Print)

A Scientific Journal of Krishi Foundation

Indexed Journal

DOI: http://dx.doi.org/ 10.3329/agric.v16i02.40346

Impact Factor: 0.568 (GIF, 2015)

\title{
Productivity and Profitability of Four Crops Based Cropping Pattern in Cumilla Region of Bangladesh
}

\author{
M. H. Hossain ${ }^{1}$, S. K. Bhowal ${ }^{1}$, M. M. Bashir ${ }^{1}$ and A. S. M. M. R. Khan ${ }^{2}$ \\ ${ }^{I}$ OFRD, Bangladesh Agricultural Research Institute (BARI), Cumilla, Bangladesh \\ ${ }^{2}$ OFRD, BARI, Gazipur, Bangladesh \\ *Corresponding author and Email: shamal.bau@gmail.com
}

Received: 08 October $2018 \quad$ Accepted: 25 December 2018

\begin{abstract}
Field experiment was conducted at the farmers' field of Amratoli, Barura multi location testing site of Cumilla during 2014-15 and 2015-16 to increase cropping intensity and productivity by inclusion of T. Aus in existing cropping pattern. Thus experiment variables were F: Existing cropping pattern (Potato -Boro-Fallow-T. Aman) and FA: Alternate cropping pattern (Potato- Boro- T. Aus- T.Aman). Research result indicated that rice equivalent yield (REY) in alternate cropping pattern was $43.46 \mathrm{t} \mathrm{ha}^{-1}$, which is $25.90 \%$ higher over existing pattern $\left(34.52 \mathrm{t} \mathrm{ha}^{-1}\right)$. Higher gross return (Tk. $\left.651900 \mathrm{ha}^{-1}\right)$, gross margin (Tk. $416520 \mathrm{ha}^{-1}$ ) and higher marginal benefit cost ratio (2.77) obtained from alternate cropping pattern messaged that this pattern may be recommended to other extrapolation areas of Cumilla region.
\end{abstract}

Keywords: Four crop sequence, potato, boro rice, T. aus, T. aman, cropping intensity.

\section{Introduction}

Bangladesh is a densely populated country with lower per capita arable land (15 decimal head $\left.{ }^{-1}\right)$ usage annual loss of agricultural land is about $0.73 \%$ per annum due to construction of houses, roads and industrial infrastructure (BBS, 2011). Thus increase of cropping intensity in rice based cropping system is becoming important for food security and poverty alleviation. In near future, the main challenge is to increase $50 \%$ yield per unit land by manipulating limited resources. In order to produce more food within a limited area, the most important options are to increase the cropping intensity and to increase the production efficiency of the individual crop by using optimum management practices (Mondol et al., 2015). Recently with the development of short duration varieties of rice, mustard, potato, pulse and jute, opportunities have been created to accommodate four crops in same piece of land in a year (BARI, 2017).

Cumilla region is highly diversified in respect to topography, agro-ecology, land-use pattern and cropping system. Among the Cumilla region, Barura upazila occupies the highest cropping intensity (CI) of $292 \%$ followed by Debidwar (265\%) and Chandina (250\%) upazila of same district which are much more higher than the national average rendering those upazilas as the most intensive cropping area of the country (Saha et al., 2017). Cumilla is the highest rice growing district in Bangladesh where PotatoBoro-Fallow-T. Aman is one of the major cropping patterns in the district (DAE, 2013). Potato is a promising cash crop in this region. As the land remains fallow after harvesting of Boro 
rice, T. Aus rice can be easily fitted in PotatoBoro-Fallow-T. Aman cropping pattern. Thus it is expected that inclusion of T. Aus in PotatoBoro-Fallow-T. Aman cropping pattern would increase cropping intensity and productivity in Cumilla region. Further, adoption of this alternate cropping pattern Potato- Boro-T. AusT. Aman can generate employment and the additional income for the rural poor of the region (Hossain et al., 2017). Considering the above issues, the present study was undertaken to ascertain feasibility of growing four crops in sequence for increasing cropping intensity, productivity and income of farm families of Cumilla region of Bangladesh.

\section{Materials and Methods}

The trial was conducted at the farmers' field of Amratoli, Barura, multi location testing site of Cumilla during 2014-15 and 2015-16 to fit T. Aus in the Potato-Boro-Fallow-T. Aman cropping pattern. The experiment was laid out in a randomized complete block design with three dispersed replications. The existing cropping pattern F: Potato-Boro-Fallow-T. Aman and alternate cropping pattern FA: Potato- Boro-T. Aus-T. Aman were the treatment variables in the experiment. Soil analysis report of the field is presented in the Table 1.

Boro rice was the first crop of the crop sequence. Fertilizer management and other intercultural operations were done according to Haque et al. (2011). Thirty five to forty days old seedling of variety BRRI dhan 28 were transplanted with 20 $\mathrm{cm} \times 15 \mathrm{~cm}$ spacing during first week of February in both existing and improved cropping pattern.

Transplanted aus (T. Aus) rice was second crop of the sequence. Fertilizer management and intercultural operations like weeding, mulching, irrigation and pest management were done according to Haque et al. (2011). Fifteen to twenty days old seedling of var. BRRI dhan48 were transplanted with $15 \mathrm{~cm} \mathrm{x} 15 \mathrm{~cm}$ spacing during first week of May in the alternate cropping pattern. Grain yield and straw yields were taken from whole plot.

Transplanted aman rice was grown during the Kharif II season and it was the third crop of the sequence. Fertilizer management and intercultural operations like weeding, mulching, irrigation and pest management were done according to Rahman et al. (2008). Seedlings were grown in adjacent plot and transplanting was done with 18-22 days old seedling of rice var. Binadhan-16 at a spacing of $20 \mathrm{~cm} \mathrm{x} 15 \mathrm{~cm}$ during first week of August in four crop based cropping pattern. T. aman rice was harvested during last week of October and yields were taken.

Potato was planted as a fourth crop during second week of November in the four crop based cropping pattern. Fertilizer management and intercultural operations like weeding, mulching, irrigation and pest management were done according to Kabir and Haque (2012). Most popular potato tubers (cv. BARI Alu-7) were planted with $60 \mathrm{~cm} \mathrm{x} 25 \mathrm{~cm}$ spacing in the cropping system field. Potato was harvested during first week of February. Tuber and foliage (over dry) weights were taken from whole plot.

Data on yield of the crops were recorded carefully and analyzed statistically by a computer program Statistix10. The gross economic return was calculated on the basis of prevailing market price of the commodities. Rice equivalent yield (REY) was determined as follows.

$\mathrm{REY}=[$ Potato yield $(\mathrm{kg}) \times$ Potato price $(\mathrm{Tk} . \mathrm{kg}$ $\left.\left.{ }^{1}\right)\right] /$ price of rice grain $\left(\mathrm{Tk} . \mathrm{kg}^{-1}\right)$.

\section{Results and Discussion}

\subsection{Yield and productivity of cropping pattern}

Yield and economic performance of alternate and existing cropping pattern during 2014-15 and 2015-16 are presented in Table $2 \&$ Table 3. The two years average grain yield of rice and tuber yield of potato in alternate cropping pattern of Potato, Boro, T. Aus, and T. Aman (Bina 
dhan-16) were recorded as $35.79,6.65,4.20$ and $4.25 \mathrm{t} \mathrm{ha}^{-1}$, respectively, where in the existing cropping pattern of Potato, Boro and T. Aman produced 29.65, 6.12 and $4.66 \mathrm{t} \mathrm{ha}^{-1}$ yield, respectively. The results clearly indicated that higher yield of Potato, Boro and T. Aman in alternate cropping pattern as compared to the existing cropping pattern.

Table 1. Initial and final soil properties of four crop based cropping pattern field at Barura, Cumilla during 2014-15 and 2015-16

\begin{tabular}{|c|c|c|c|c|c|c|c|c|}
\hline \multirow[t]{2}{*}{ Soil Properties } & \multirow[t]{2}{*}{$\begin{array}{l}\text { Land } \\
\text { type }\end{array}$} & \multirow[t]{2}{*}{$\mathrm{pH}$} & \multirow[t]{2}{*}{$\begin{array}{c}\text { Organic } \\
\text { matter }(\%)\end{array}$} & $\mathrm{K}$ & \multirow{2}{*}{$\begin{array}{c}\text { Total } \\
\mathrm{N} \\
(\%)\end{array}$} & $\mathrm{P}$ & $\mathrm{Zn}$ & B \\
\hline & & & & Meq100 $\mathrm{ml}^{-1}$ & & \multicolumn{3}{|c|}{$\mu \mathrm{gml}^{-1}$} \\
\hline Initial & MHL & 5.4 & 1.85 & 0.14 & 0.14 & 10.5 & 2.78 & 0.20 \\
\hline Final & MHL & 5.5 & 1.86 & 0.10 & 0.09 & 28.5 & - & 0.45 \\
\hline Critical Level & - & - & - & 0.12 & 0.12 & 8.0 & 0.6 & 0.20 \\
\hline
\end{tabular}

Table 2. Agronomic performance of different crops at farmers and alternate cropping pattern at Barura, Cumilla (Averaged over two years data)

\begin{tabular}{|c|c|c|c|c|c|c|c|c|}
\hline \multirow[t]{2}{*}{ Parameters } & \multicolumn{4}{|c|}{$\mathrm{F}:$ Farmers cropping pattern } & \multicolumn{4}{|c|}{ FA : Farmers alternate cropping pattern } \\
\hline & Boro & Fallow & T. Aman & Potato & Boro & T. Aus & T. Aman & Potato \\
\hline Variety & $\begin{array}{c}\text { BRRI } \\
\text { dhan28 }\end{array}$ & - & $\begin{array}{c}\text { BRRI } \\
\text { dhan32 }\end{array}$ & $\begin{array}{l}\text { BARI } \\
\text { Alu-7 }\end{array}$ & $\begin{array}{c}\text { BRRI } \\
\text { dhan28 }\end{array}$ & $\begin{array}{c}\text { BRRI } \\
\text { dhan48 }\end{array}$ & $\begin{array}{c}\text { Binadhan- } \\
16\end{array}$ & $\begin{array}{l}\text { BARI } \\
\text { Alu-7 }\end{array}$ \\
\hline $\begin{array}{l}\text { Planting } \\
\text { date }\end{array}$ & $\begin{array}{l}\text { 04-06 } \\
\text { Feb. }\end{array}$ & - & $\begin{array}{l}\text { 01-04 } \\
\text { Aug. }\end{array}$ & $\begin{array}{l}18-20 \\
\text { Nov. }\end{array}$ & $\begin{array}{l}\text { Seed bed, } \\
29 \text { Dec. } \\
\text { Transplanted } \\
\text { 05 Feb. }\end{array}$ & $\begin{array}{c}\text { Seed bed, } \\
16 \text { Apr. } \\
\text { Transplantec } \\
\text { 07 May. }\end{array}$ & $\begin{array}{l}\text { Seed bed, } 07 \\
\text { Jul. } \\
\text { Transplanted } \\
\text { 5-8 Aug. }\end{array}$ & 14 Nov. \\
\hline $\begin{array}{l}\text { Harvesting } \\
\text { date }\end{array}$ & 26 April. & - & 10 Nov. & 30-31 Jan. & 26-27Apr. & 03 Aug. & 23-27 Oct. & 02 Feb. \\
\hline $\begin{array}{l}\text { Field } \\
\text { duration }\end{array}$ & 82 & - & 98 & $73-74$ & $82-84$ & 87 & 78 & 80 \\
\hline $\begin{array}{l}\text { Turn } \\
\text { around } \\
\text { time }\end{array}$ & 06 & 103 & 10 & 04 & 02 & 06 & 06 & 18 \\
\hline $\begin{array}{l}\text { Grain } \\
\text { Yield } \\
\left(\mathrm{t} \mathrm{ha}^{-1}\right)\end{array}$ & 6.12 & - & 4.66 & 29.65 & 6.38 & 4.20 & 4.25 & 35.79 \\
\hline $\begin{array}{l}\text { Straw } \\
\text { Yield } \\
\left(\mathrm{t} \mathrm{ha}^{-1}\right)\end{array}$ & 6.37 & & 4.80 & 2.28 & 6.17 & 4.47 & 4.85 & 2.18 \\
\hline $\operatorname{LSD}_{(0.05)}$ & 0.132 & - & 0.054 & 0.462 & 0.131 & 0.122 & 0.124 & 0.455 \\
\hline $\mathrm{CV}(\%)$ & 6.15 & - & 8.11 & 5.12 & 6.56 & 4.55 & 8.15 & 6.15 \\
\hline
\end{tabular}


Table 3. Economic performance of farmers and alternate cropping pattern at Barura, Cumilla

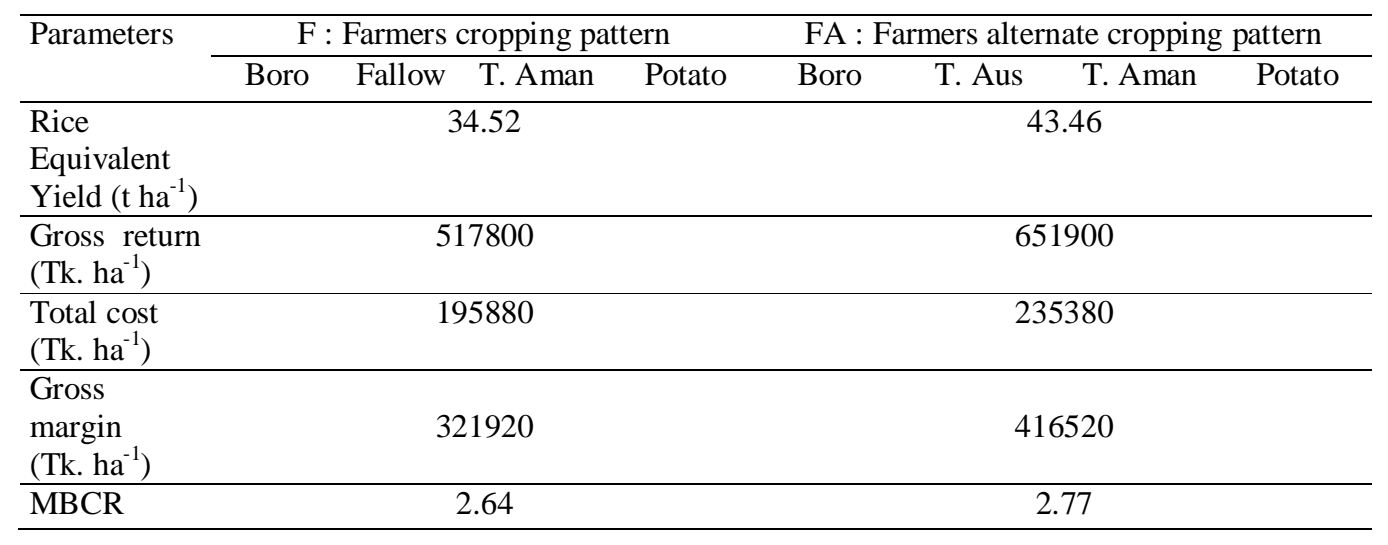

Total productivity of different cropping sequences was determined by Rice Equivalent Yield (REY) which was calculated from yield of component crops. Rice equivalent yield was different under different cropping sequences. From the results of two years research on four crop based cropping pattern, it was observed that the average higher REY (43.46 $\left.\mathrm{t} \mathrm{ha}^{-1}\right)$ was recorded from the alternate cropping sequence than the existing cropping sequence $\left(34.52 \mathrm{t} \mathrm{ha}^{-}\right.$ $\left.{ }^{1}\right)$. Rice equivalent yield in the improved cropping pattern was $25.90 \%$ higher than the existing cropping pattern due to inclusion of one cereal crop (T. Aus) and use of modern varieties and other technologies in the alternate cropping pattern. The result of the study similar with the Naher et al. (2016) and Hossain et al. (2014) who stated that short duration varieties and improved four crop based cropping pattern increases total productivity and profitability over farmers existing pattern.

\subsection{Economic analysis}

Economic analysis was done on the basis of prevailing market price of the commodities. Productivity of different cropping systems were compared in terms of rice equivalent yield. Economics of system productivity of alternate and existing cropping sequences showed in Table 3 and It was observed that gross return was different for different cropping patterns. Higher gross return (Tk. $651900 \mathrm{ha}^{-1}$ ) and gross margin (Tk. $416520 \mathrm{ha}^{-1}$ ) were obtained in alternate Boro-T. Aus-T. Aman-Potato cropping pattern as compared to existing cropping pattern. Higher economic return recorded from alternate cropping sequence Boro-T. Aus-T. AmanPotato, was the result of increase of total productivity than the existing one. Higher (2.77) MBCR was also found in Boro-T. Aus-T. AmanPotato cropping pattern as compared to farmers existing cropping pattern (2.64). Other authors (Mondal et al., 2014) agreed that the four crop based cropping pattern would play a vital role to ensure food security of the country in upcoming days.

\section{Conclusions}

Based on two years average results of the cropping pattern research, it may be concluded that four crop based cropping pattern PotatoBoro-T. Aus-T. Aman is agronomically feasible and economically profitable compared to existing farmers cropping pattern Potato-BoroFallow-T. Aman. As the alternate cropping pattern was found more productive and economical it may be recommended to other extrapolation areas to increase crop production in Cumilla region of Bangladesh. 


\section{References}

BARI (Bangladesh Agricultural Research Institute) 2017. Krishi Projukti Hatboi (Handbook on Agro-Technology), 7th edition, Gazipur-1701, Bangladesh

BBS (Bangladesh Bureau of Statistics) 2011. Statistical Yearbook of Bangladesh. Bangladesh Bureau of Statistics, Ministry of Planning. Dhaka. Bangladesh

DAE (Department of Agricultural Extension) 2013. Annual research-extension regional review workshop. Khamarbari, Cumilla, Bangladesh

Haque AKGMN., Basher MK., Islam MS and Khasem MA. 2011. Modern Rice Cultivation, $16^{\text {th }}$ edition. Bangladesh Rice research Institute, Gazipur-1701

Hossain MH., Bashir MM., Bhowal SK., Naher Q., Zahan T., Hasan MK. and Khan ASMMR. 2017. Production technology of four crop based cropping pattern MustardBoro-T. Aus-T. Aman rice in Cumilla region (Bengali Booklet). OFRD (OnFarm Research Division), BARI, Bangladesh, $23 \mathrm{p}$.

Hossain I., Mondal RI., Islam MJ., Aziz A., Khan ASMMR. and Begum F. 2014. Four crop based cropping pattern studies for Increasing Cropping Intensity and Productivity in Rajshahi region of Bangladesh. Bangladesh Agronomy Journal, 17(2):55-60.
Kabir KH., Haque MZ. 2012. Alu Chash er Adhunik Kola kowshal (Modern Production Technology of Potato), 1st edition, TCRC, BARI, Gazipur, Bangladesh

Mondal RI., Begum F., Aziz A. 2014. Four crop based cropping pattern in one piece of land in a year (T. Aman -Mustard-Boro-T. Aus rice). (Bengali Booklet) Bangladesh Agricultural research Institute, Gazipur170, Bangladesh. 31 p.

Mondal RI., Begum F., Aziz A., Sharif SH. 2015. Crop Sequences for Increasing Cropping Intensity and Productivity. SAARC Journal of Agriculture, 13(1):135147.

Naher Q., Amin MR., Islam MR., Ali MA., Choudhury AK., Hasan MK., Khan ASMMR. 2016. Location specific climate resilient agricultural technologies in Banglaesh. OFRD (On-Farm Research Division), BARI, Bangladesh. 37-38 pp.

Rahman MS., Satter MA., Begum N., Hyder MR. 2008. Unnata Krishi Projukti Porichity. Bangladesh Institute of Nuclear Agriculture (BINA), Mymensingh, Bangladesh

Saha A., Nasim M., Rashid MH., Sahidullah SM. 2017. Crop diversity and cropping patterns of Cumilla region. Bangladesh Rice Journal, 21 (2): 91-105 pp. 